\title{
Cyberspace as an Area of Legal Regulation
}

\author{
Katarzyna Chałubińska-Jentkiewicz
}

\begin{abstract}
The rapid development of the Internet, which rose to prominence at the turn of the twenty-first century, is one of the most significant technological breakthroughs in human history. Cyberspace has now become the environment for the functioning of modern society, particularly the young generation. Under the influence of globalisation, computerisation and digitisation, human activity began to penetrate the virtual world. This shift has contributed to raising the standard and quality of life of citizens, increasing the productivity of entrepreneurs and the efficiency of the state. However, the changes have resulted in society's increasing dependence on cyberspace and created the need to protect the public against potential attacks. Specifying the definition of cyberspace security was required in the course of developing the Cybersecurity Doctrine of the Republic of Poland.
\end{abstract}

The dynamic civilisational changes which have been observed in the last few years have arisen from a rapid growth in information and supporting ICT technologies. The information revolution and the evolution of the information society, which affect every sphere of human activity, are undoubtedly two of the major trends shaping the contemporary information environment. Access to new technologies, and the fact that they are so commonly used by the public, have created a need for distinguishing another dimension of physical reality, namely cyberspace. The convergence of information and communications technologies and the media, which has been intensifying for at least a quarter of a century, and, in consequence, the convergence of the info-, socio- and techno-spheres, has contributed to the emergence of a global, timeless cyberspace, not defined by either geographical or political borders.

The development of the Internet, the worldwide computer network, towards the end of the twentieth Century, was one of the most significant technological

\footnotetext{
K. Chałubińska-Jentkiewicz $(\bowtie)$

Akademickie Centrum Polityki Cyberbezpieczeństwa/Academic Center for Cybersecurity

Policy, Akademia Sztuki Wojennej w Warszawie/War Studies University in Warsaw, Warsaw,

Poland

e-mail: k.jentkiewicz@akademia.mil.pl
} 
breakthroughs in the history of humanity. At first it was used exclusively in scientific research; as time went by, and as the tools making it easier to use the Internet were developed, it became a key and fundamental element in the functioning of individuals in all spheres of life. ${ }^{1}$ Falling in the Cold War period, the 1960s marked the beginning of the computer network. In that period, a communications system was created in the United States, which gave rise to the ARPANET network (Advanced Research Projects Agency Network), considered to be the first prototype of the Internet. The combination of information and telecommunications technologies ushered in a new era of global communication. By the end of the 1990s, the growth of the Internet had made many spheres of life which were based on computer technology dependent on the net. It became a tool whereby people could enrich their knowledge, a source of information, and an integration point. ${ }^{2}$ The domain underwent rapid commercialisation and development. New services sprang into existence-websites, social networks, electronic mail, forums, blogs, search engines, instant messaging, multimedia streaming, to name a few. The expansion of the physical infrastructure of the global network has resulted in a steady growth in the number of Internet users. As the information society continues to develop rapidly commensurately with the expansion of the reach of the Internet, other areas of human activity extend into cyberspace. Instant access to the Internet from almost every place on Earth, and its worldwide reach, in connection with low usage fees, have made more and more entities (governments, institutions and businesses) and individuals move large parts of their daily activities to the virtual network. ${ }^{3}$

Cyberspace has become a domain which pertains to many areas of human life. Although still considered a "novum", the term was first used in the 1980s by W. Gibson, who described it as follows:

A consensual hallucination experienced daily by billions of legitimate operators, in every nation, by children being taught mathematical concepts [...]. A graphical representation of data abstracted from the banks of every computer in the human system. Unthinkable complexity... Lines of light ranged in the non-space of the mind, clusters and constellations of data. ${ }^{4}$

Gibson pointed out some characteristic features of the environment: unlimited time and space, virtuality, complexity, and the collation of all resources in one huge database. ${ }^{5}$ Visualisation, in Gibson's words "a graphical representation", has become characteristic of a trend called cyberpunk. ${ }^{6}$

\footnotetext{
${ }^{1}$ Ciekanowski and Wojciechowska-Filipek (2016), p. 91.

${ }^{2}$ Ciekanowski and Wojciechowska-Filipek (2016), p. 14.

${ }^{3}$ M. Grzelak, K. Liedel, Bezpieczeństwo w cyberprzestrzeni. Zagrożenia i wyzwania dla Polskizarys problemu. https://www.bbn.gov.pl/download/1/11469/str125139MichalGrzelakKrzysztofLiedel.pdf (accessed on 01.10.2020).

${ }^{4}$ Gibson (2009), Katowice, p. 59.

${ }^{5}$ Szczepaniuk (2016), p. 69.

${ }^{6}$ Cyberpunk is a subgenre of fantasy literature and cinematography which foregrounds the relationship between man and the advanced technology which surrounds him. The defining feature of
} 
At the beginning of the last decade of the last century, during the Gulf War (1991), which was the first information war, ${ }^{7}$ there appeared a thesis that cyberspace had become the fifth environment (besides land, sea, air, and the cosmos) in which combat and warfare were being conducted (Warden's model). ${ }^{8}$

P. Sienkiewicz set out to interpret the essence of the construct called cyberspace. He distinguished the following basic perspectives from which the topic can be approached.

- "Cyberspace is essentially a huge social network - a net of nets, the participants in which, either individuals or groups (societies), utilise global resources provided by the Internet (generally speaking, the net)

- Cyberspace is identified with the virtual reality generated by the computer, the network, and the Internet

- Cyberspace is simply the Internet, its resources, services, and users

- Cyberspace is merely an evolving, dynamic, complex, system (a system of systems), and it should be seen as such, no matter whether we foreground its technical, informational, or social aspects".

"In physical terms, cyberspace may be characterised by Maxwell's four equations, which are

- Gauss's law for electric fields

- Faraday's law of induction

- Gauss's law for magnetism

- Ampère's law (further developed by Maxwell)". ${ }^{10}$

The capability of analysing, generating, receiving, and measuring fluctuating electric and magnetic fields was knowingly applied, for the first time, in a device called the telegraph. ${ }^{11}$

D. E. Denning defines cyberspace (its technical aspect) as "[...] the space of information created by all computer networks put together". ${ }^{12}$ A similar definition is formulated by G. T. Rattray. "A physical domain which is the result of the creation of information systems and networks which enable mutual interactions through electronic communication". ${ }^{13}$ P. Sienkiewicz defines cyberspace in the technical dimension. "[...] a global network made of a time-variable number of constituent

the genre is depiction of a vision of a future in which the environments of people, appliances, and computers start to permeate one another.

${ }^{7}$ Campen (1996), p. 11.

${ }^{8}$ Warden (1995).

${ }^{9}$ Sienkiewicz (2015), pp. 89-102.

${ }^{10}$ Słota-Bohosiewicz (2015), pp. 155-166.

${ }^{11}$ Ibidem.

${ }^{12}$ Denning (2002), p. 24.

${ }^{13}$ Rattray (2004), p. 30. 
networks (TCP/IP), with unlimited and open resources and available services". ${ }^{14}$ In the above definitions cyberspace is compared to computer systems operating within computer networks.

One of the definitions of cyberspace cited in literature is the one provided by the United States Department of Defence. According to this definition, cyberspace is

A global domain within the information environment consisting of an interdependent network of information technology infrastructures and resident data, including the Internet, telecommunications networks, and embedded processors and controllers.

The above definition refers merely to the technological dimension of cyberspace. It does not make any references to the social sphere-to mankind, the user of cyberspace. In addition, the definition firmly ascribes the hardware aspect of infrastructure with the leading role of the Internet, whereas the software aspect is overlooked. ${ }^{15}$

In Europe one can refer to a series of definitions adopted in official documents released by various countries, and by the European Union. The European Commission defines it in the following way. "Virtual space in which electronic data circulate, and are processed by PC computers from all over the world.". ${ }^{16}$ The basic element of this definition is virtual space's constituting a data system which is accessed through ICT systems. The interpretation by the European Commission also disregards the user sphere.

Another, more exhaustive definition, of cyberspace is proffered by the NATO Cooperative Cyber Defence Centre of Excellence in Tallinn, which says "Cyberspace is a time-dependent set of interconnected information systems and people/ users who interact with those systems". ${ }^{17}$ The need to regulate the matters related to cyberspace security has been reflected in a large number of strategic documents and legislation. NATO's new strategic concept ${ }^{18}$ and updated cyber-defence policy identify cyber threats, in special cases, as potential reasons for exercising collective defence. ${ }^{19}$

In accordance with the Polish regulations, cyberspace is defined as "virtual space in which information is processed and exchanged by ICT systems, as set out in Article 3(3) of the Act of 17 February 2005 on the Computerisation of the Operations of the Entities Rendering Public Services, ${ }^{20}$ and the interrelations between the

\footnotetext{
${ }^{14}$ Sienkiewicz (2012), p. 324.

${ }^{15}$ Szczepaniuk (2016), p. 71.

${ }^{16}$ Wasilewski (2013), p. 229.

${ }^{17}$ R. Otis, P. Lorents, Cyberspace: Definition and Implications, the Cooperative Cyber Defence Centre of Excellence, Tallinn. http://dumitrudumbrava.files.wordpress.com/2012/01/cyberspacedefinition-and-impications.pdf (accessed on 01.10.2020).

${ }^{18}$ A Strategic Concept for the Defence and Security of the Members of the North Atlantic Treaty Organisation, Lisbon 2010. https://www.bbn.gov.pl/download/1/15758/ KoncepcjastrategicznaNATO.pdf (accessed on 01.10.2020).

${ }^{19}$ Szczepaniuk (2016), p. 72.

${ }^{20}$ I.e. consolidated text Polish Journal of Laws of 2020, item 346, as amended, hereinafter the Computerisation Act.
} 
entities and the relationships with users". ${ }^{21}$ Cyberspace is therefore a generalisation of the concepts of "systems" and "ICT networks". An essential aspect of defining cyberspace is the relationships between its users.

In that respect, this definition converges with the one proposed by $\mathrm{CCDCoE}^{22}$ since it includes both the human and the technical components of cyberspace. One of the essential aims of its amendments was to introduce the category of cyberspace as one of the constituents of national security. The introduction of the definition became especially important to the institutions and bodies which were in charge of broadly understood security, allowing one to create a power instrumentarium, necessary for those entities to perform tasks in accordance with the constitutional principle of legalism. The solutions adopted complied with NATO's Strategic Concept from $2010,{ }^{23}$ which was in effect at that time, and at the same time they complemented the Cyberspace Protection Policy of the Republic of Poland for 2011-2016 ${ }^{24}$ prepared by the Council of Ministers.

In accordance with this document, the following definition of cyberspace was adopted.

- "Cyberspace - a digital space for processing and exchanging information created by ICT systems and networks, together with the connections between one another and relationships with the users;

- The cyberspace of the Republic of Poland (hereinafter CRP)—cyberspace within the territory of the Polish State, and in locations outside that territory, in which representatives of the Republic of Poland (diplomatic posts, military contingents) operate". 25

Cybersecurity had to be defined in view of the works which were meant to develop the Doctrine of the Cybersecurity of the Republic of Poland. The document contains the following definition.

A part of the State's cybersecurity which covers a range of organisational, legal, technical, physical, and educational ventures aimed at ensuring the uninterrupted functioning of the

\footnotetext{
${ }^{21}$ The Act of 29 August 2002 on Martial War and the Powers of the Commander-in-Chief and the Rules of His Subordination to the Constitutional Bodies of the Republic of Poland, i.e. consolidated text The Polish Journal of Laws of 2017, item 1932.

${ }^{22}$ NATO CCDCoE, officially the Cooperative Cyber Defence Centre of Excellence, is one of NATO Centres, based in Tallinn, Estonia. The centre conducts research and training in cybernetic security.

${ }^{23}$ Translation by the National Security Bureau: Andrzej Juszczak, 17 January 2011. https://www. bbn.gov.pl/pl/wydarzenia/2694, dok.hml (accessed on 27.01.2020).

${ }^{24}$ Werner (2014), p. 36.

${ }^{25}$ The Cyberspace Protection Policy of the Republic of Poland for 2011-2016. http://bip.msw.gov. pl/bip/programy/19057,Rządowy-Program-Ochrony-Cyberprzestrzeni-RP-na-lata-2011-2016.html (accessed on 28.10.2020).
} 
cyberspace of the Republic of Poland, together with its critical public and private ICT infrastructure, and the security of the information processed within that infrastructure. ${ }^{26}$

This definition emphasises the functional aspect of cybersecurity, i.e. activities of which the aim is to protect that space and its users.

One of the defining features of cyberspace is its network character. It is very often associated with the information revolution, and is undoubtedly connected with the rapid growth of telecommunications and the popularisation of the Internet. ${ }^{27}$ The network character is to be understood as a constitutive attribute of cyberspace, virtuality, a potential one, and as far as the communication advantages are concerned, one should not overlook hypertextuality, multimediality, and interactiveness. "The combination of constitutive features and their semantic interrelations is one of the ontological aspects of cyberspace". ${ }^{28}$ Computer networks are a system of interrelated workstations, peripheral devices (such as printers, hard drives, scanners and workstations), and other devices. Computer networks, because of their functionality, constitute the core of all computer systems. By working within a computer network, one can share data, hardware and software, and manage all the devices connected with that network from one computer. ${ }^{29}$

These days, cyberspace has become an environment in which contemporary society, especially its young generation, lives and functions. Affected by globalisation, computerisation or digitalisation, human activity has begun to permeate the virtual world. This has contributed to the raising of the living standards and the quality of the lives of citizens, and has boosted the productiveness of entrepreneurs and the efficiency of the State. The consequence of those changes, which are becoming more and more evident, is society's dependence on cyberspace. This dependence requires the reliability of the ICT infrastructure, which in turn involves protection against potential attacks. ${ }^{30}$ Cyberspace affords huge opportunities, such as e-learning, e-administration, and telecommuting, but has its "dark side" as well. In the field of cybersecurity one can observe an increase in the number of incidents of various kinds. Cyber attacks can also have a destructive influence on the State's critical infrastructure, the functioning of which is based, to a large extent, on ICT systems. $^{31}$

Space associated with certain real places has been replaced with the space of flows, as wrote M. Castells. Formerly, space was defined geographically, whereas today it consists of various layers of unimaginable complexity. ${ }^{32}$

The table below sets out the development stages of cyberspace (Table 1).

\footnotetext{
${ }^{26}$ The Doctrine of the Cybersecurity of the Republic of Poland. https://www.bbn.gov.pl/pl/pracebiura/publikacje/6818,Doktryna-cyberbezpieczenstwa-RP.html (accessed on 27.01.2021).

${ }^{27}$ Szczepaniuk (2016), p. 69.

${ }^{28}$ Sienkiewicz (2015), p. 92.

${ }^{29}$ Szczepaniuk (2016), p. 70.

${ }^{30}$ Chałubińska-Jentkiewicz (2019), p. 18.

${ }^{31}$ Szczepaniuk (2016), p. 84.

${ }^{32}$ Ibidem, p. 71.
} 
Table 1 An evolutionary stage model of cyberspace

\begin{tabular}{|c|c|}
\hline $\begin{array}{l}\text { Development } \\
\text { stage }\end{array}$ & General description \\
\hline Cyberspace- 0 & $\begin{array}{l}\text { - "The Gutenberg Galaxy" (M. McLuhan) } \\
\text { - The development of print and the beginnings of telegraphy, telecommunica- } \\
\text { tions; radio, television }\end{array}$ \\
\hline Cyberspace-1 & $\begin{array}{l}\text { - "Galaktyka Wienera" (P. Sienkiewicz) [T.N. - in Polish "Wiener's Galaxy"] } \\
\text { - "The information society" (Masuda) } \\
\text { - Cybernetic concepts of the development of social systems, the evolution of } \\
\text { digital electronics, computer systems, satellite communications (TELSTAR), } \\
\text { the computer network (ARPANET), "PC boom" } \\
\text { - Artificial intelligence }\end{array}$ \\
\hline Cyberspace-2 & $\begin{array}{l}\text { - "The Internet Galaxy" (M. Castells) } \\
\text { - The Internet (WWW), the knowledge-based economy, globalisation }\end{array}$ \\
\hline Cyberspace-3 & $\begin{array}{l}\text { - "The Galaxy?" (we can't predict) } \\
\text { - The Internet (Web 2.0), the globalisation of the social-communications } \\
\text { network, new forms of social behaviour } \\
\text { - "The knowledge society" (we can't predict) }\end{array}$ \\
\hline
\end{tabular}

Source: Sienkiewicz (2012) op. 324

The raising of awareness related to secure cyberspace goes hand in hand with rapid increases in the number of computer incidents, and new categories of threats. Poland is also a target for attacks on its cyberspace. Similarly to other countries, it is faced with the challenge of working out organisational and legal changes which will ensure an appropriate level of cybersecurity, and the security of the citizens who function within that space. ${ }^{33}$

In the field of cybersecurity, there are such new terms as information security, computer-network and computer-systems security, ICT security, and cybersecurity. According to P. Potejko,

\begin{abstract}
one can assume that information security consists of a set of activities, methods, and procedures employed by competent authorities which are aimed at ensuring the integrity of collected, stored and processed information resources by protecting them against undesirable, unauthorised disclosure, modification or destruction. ${ }^{34}$

The Cybersecurity Strategy of the Republic of Poland ${ }^{35}$ defines IT security as

[...] the resilience of ICT systems, with a given level of trust, to counter any actions or activities which violate the accessibility, authenticity, integrity, or confidentiality of the data which are stored, shared, or processed, or related services afforded or rendered via those computer networks and systems $[\ldots]^{36}$.
\end{abstract}

\footnotetext{
${ }^{33}$ Werner (2014), p. 31.

${ }^{34}$ Potejko (2015), p. 228.

${ }^{35}$ The Cybersecurity Strategy of the Republic of Poland for 2017-2022. https://mc.gov.pl/ aktualnosci/strategia-cyberbezpieczenstwa-rzeczypospolitej-polskiej-na-lata-2017-2022 (accessed on 24.05.2020).

${ }^{36}$ Ibidem, p. 23.
} 
By comparison, the Cybersecurity Strategy of the European Union ${ }^{37}$ defines cybersecurity as

the safeguards and actions which can be used to protect the cyber domain, in both the civilian and the military fields, from those threats associated with or which might harm its interdependent networks and information infrastructure. Cybersecurity strives to preserve the availability and integrity of these networks and infrastructure, and the confidentiality of the information contained therein. ${ }^{38}$

In the States which are involved in the development of the information society, cybersecurity is considered one of the most serious challenges in the realm of national security. It refers to both the security of the State and of its individual citizens. The appropriate functioning of public administration is highly important for the maintenance of cybersecurity. The last few years have also brought a revolution in the understanding of the concept of national security as regards the subject matter. One has begun to notice the significance of not only military or political aspects, but also economic, cultural, ecological and ideological facets, among others. Seeing those changes, the Polish State has started to develop the National Security System, the primary focus of which is to ensure broadly understood integrated national security, in which cybersecurity occupies a very important place, covering all other aspects of social life. $^{39}$

The increased significance of cyberspace in the functioning of numerous aspects of the State and society has brought the development of national and international cybersecurity strategies, and the further development of cybersecurity management systems.

\section{References}

Campen S (ed) (1996) The first information. AFCEA, Washington

Ciekanowski Z, Wojciechowska-Filipek S (2016) Bezpieczeństwo funkcjonowania w cyberprzestrzeni Jednostki - Organizacji - Państwa, Warsaw

Chałubińska-Jentkiewicz K (2019) Cyberbezpieczeństwo - zagadnienia definicyjne. Cybersecurity and Law 2

Denning DE (2002) Wojna informacyjna i bezpieczeństwo informacji [T.N. - original title: Information Warfare and Security], Warsaw

Gibson W (2009) Neuromancer, Katowice

Grzelak M, Liedel K. Bezpieczeństwo w cyberprzestrzeni. Zagrożenia i wyzwania dla Polski zarys problemu. https://www.bbn.gov.pl/download/1/11469/str125139MichalGrzelakKrzysztofLiedel.pdf. Accessed 1 Oct 2020

\footnotetext{
${ }^{37}$ The Cybersecurity Strategy of the European Union: An Open, Safe and Secure Cyberspace, OJ EU C 2014.32.19., http://www.europarl.europa.eu/meetdocs/2009_2014/documents/join/com_join (2013)0001_/com_join(2013)0001_pl.pdf, hereinafter the Cybersecurity Strategy of the European Union (accessed on 12.10.2020).

${ }^{38}$ Ibidem, p. 3.

${ }^{39}$ Chałubińska-Jentkiewicz (2019), p. 20.
} 
Otis R., Lorents P, Cyberspace: Definition and Implications, the Cooperative Cyber Defence Centre of Excellence, Tallinn. http://dumitrudumbrava.files.wordpress.com/2012/01/cyberspace-defini tion-and-impications.pdf. Accessed 1 Oct 2020

Potejko P (2015) Bezpieczeństwo informacyjne. In: Chałubińska-Jentkiewicz K, Karpiuk M (eds) Prawo nowych technologii - wybrane zagadnienia. Warsaw

Rattray GT (2004) Wojna strategiczna w cyberprzestrzeni [T.N. - original title: Strategic Warfare in Cyberspace], Warsaw

Sienkiewicz P (2012) Bezpieczeństwo cyberprzestrzeni. In: Sienkiewicz P (ed) Metodologia badań bezpieczeństwa narodowego, vol 3. Warsaw

Sienkiewicz P (2015) Ontologia cyberprzestrzeni. Zeszyty Naukowe Warszawskiej Wyższej Szkoły Informatyki 13(9)

Słota-Bohosiewicz A (2015) Zarzadzanie bezpieczeństwem w cyberprzestrzeni obywatela. In: Wybrane aspekty bezpieczeństwa cybernetycznego sił zbrojnych Rzeczypospolitej Polskiej. vol. 2, Warsaw

Szczepaniuk E (2016) Bezpieczeństwo struktur administracyjnych w warunkach zagrożeń cyberprzestrzeni państwa, Warsaw

Warden JA (1995) The enemy as a system. Airpower Journal 9(1)

Wasilewski J (2013) Zarys definicyjny cyberprzestrzeni. Przegląd Bezpieczeństwa Wewnętrznego 9

Werner J (2014) Zagrożenia bezpieczeństwa w cyberprzestrzeni. Warsaw

Katarzyna Chałubińska-Jentkiewicz dr. hab. of legal sciences (University of Warsaw and the Jagiellonian University), legal advisor, associate professor, and head of the Department of Cybersecurity Law and New Technologies at the Institute of Law in the Faculty of National Security at the War Studies University in Warsaw. She is also a lecturer at the SWPS University and director of the Academic Center for Cybersecurity Policy. In the years 1996-2010, she worked as a lawyer in the National Broadcasting Council and with the public broadcaster TVP S.A. Between 2011 and 2017, she was deputy director of the National Audiovisual Institute (her competence centered on the field of digitization). As a scientist, she conducts research on cybersecurity, information security threats, the development of electronic media law, protection of intellectual property, and the impact of new technologies on the development of the state and the legal situation of the individual. Katarzyna Chałubińska-Jentkiewicz is the author of monographs and numerous articles, which include topics such as new technologies law, cyber responsibility, information security law, and audiovisual media: Regulatory conflict in the age of digitization, Audio visual media services; Regulation in the conditions of digital conversion; Information and computerization in public administration; Cultural Security Law and Reuse of public sector information. She is head of the Ministry of Science's research project "Polish cybersecurity system - a model of legal solutions."

Open Access This chapter is licensed under the terms of the Creative Commons Attribution 4.0 International License (http://creativecommons.org/licenses/by/4.0/), which permits use, sharing, adaptation, distribution and reproduction in any medium or format, as long as you give appropriate credit to the original author(s) and the source, provide a link to the Creative Commons license and indicate if changes were made.

The images or other third party material in this chapter are included in the chapter's Creative Commons license, unless indicated otherwise in a credit line to the material. If material is not included in the chapter's Creative Commons license and your intended use is not permitted by statutory regulation or exceeds the permitted use, you will need to obtain permission directly from the copyright holder.

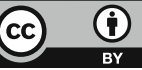

